\title{
MENGEMBANGKAN KETERAMPILAN MEMECAHKAN MASALAH MELALUI PEMBELAJARAN BERDASAR MASALAH
}

\author{
Imami Arum Tri Rahayu, \\ Gde Agus Yudha Prawira Adistana \\ Universitas Negeri Surabaya \\ E-mail: inggard.vido@gmail.com.id
}

\begin{abstract}
Abstrak
Kemampuan pemecahan masalah merupakan salah tujuan pembelajaran level tinggi dalam ranah kognitif. Beberapa penelitian menunjukkan bahwa dengan menggunakan model pembelajaran tertentu memberikan dampak peningkatan yang signifikan terhadap peningkatan hasil belajar kognitif. Penelitian ini merupakan penelitian tindakan kelas kolaboratif yang bertujuan untuk mengetahui bagaimana pengaruh penggunaan model pembelajaran berbasis masalah terhadap kemampuan pemecahan masalah dan sikap sosial pebelajar. Penerapan model pembelajaran berbasis masalah dilakukan selama dua siklus dan pengukuran hasil belajar dilakukan dengan menggunakan instrumen penilaian non-test berupa lembar penilaian. Analisis data selanjutnya dilakukan dengan menggunakan metode penskoran. Hasil penelitian menunjukkan bahwa pada siklus satu kemampuan pemecahan masalah siswa belum optimal karena tujuh puluh lima persen subyek tidak berhasil menyelesaikan permasalahan. Selain itu, masih banyak ditemukan sikap yang tidak relevan dengan proses pembelajaran. Pada siklus kedua terjadi peningkatan kemampuan pemecahan masalah dengan indikasi bahwa tujuh puluh lima persen siswa mampu menyelesaikan permasalahan yang diberikan dan disertai dengan penurunan sikap yang tidak relevan.
\end{abstract}

Kata Kunci: pemecahan masalah, social behavior, hasil belajar kognitif

\begin{abstract}
Problem solving ability is a high level learning goal in the cognitive domain. Some studies show that using certain learning models has a significant impact on improving cognitive learning outcomes. This research is a collaborative classroom action research which aims to find out how the influence of the use of problem-based learning models on students' problem solving abilities and social attitudes. The application of the problem-based learning model was carried out for two cycles and the measurement of learning outcomes was carried out using a non-test assessment instrument in the form of an assessment sheet. Data analysis is then carried out using the scoring method. The results showed that in the cycle one the problem solving ability of students was not optimal because seventy-five percent of the subjects did not succeed in solving the problem. In addition, there are still many attitudes that are not relevant to the learning process. In the second cycle there is an increase in problem solving ability with an indication that seventy-five percent of students are able to solve the problems given and accompanied by a decrease in irrelevant attitudes.
\end{abstract} Keywords: problem solving, social behavior, cognitive learning outcomes 


\section{PENDAHULUAN}

Setiap manusia harus memiliki kemampuan memecahkan masalah untuk mencapai tujuan yang diinginkan. Dalam berbagai aspek kehidupan kemampuan memecahkan masalah terutama yang berkaitan dengan masalahmasalah praktis yang membutuhkan solusi yang layak secara ekonomis, tepat waktu, serta pertimbangan dapat tidaknya untuk diimplementasikan sangatlah penting (Chaudhry \& Rasool, 2012)

Dewey mengemukakan bahwa sekolah seharusnya mencerminkan masyarakat yang lebih besar dan kelas merupakan laboratorium untuk memecahkan masalah kehidupan nyata. Pembelajar mendorong si belajar untuk terlibat dalam proyek atau tugas berorientasi pada masalah dan membantu mereka menyelidiki masalahmasalah intelektual dan sosial. Dewey juga menyatakan bahwa pembelajaran disekolah seharusnya lebih memiliki manfaat dari pada abstrak dan pembelajaran yang memiliki manfaat terbaik dapat dilakukan oleh siswa dalam kelompok-kelompok kecil untuk menyelesaikan proyek yang menarik dan pilihan mereka sendiri.

Menurut (Adistana, 2016) untuk dapat memiliki kemampuan pemecahan masalah maka pemahaman tentang konsep-konsep abstrak dan prosedur-prosedur yang terkait atau aplikasi kaidah-kaidah adalah sangat diperlukan. Dengan kata lain, untuk dapat memecahkan masalah dengan benar, maka pebelajar perlu menguasai bagaimana mengaplikasikan dua pengetahuan yaitu pengetahuan konseptual dan pengetahuan prosedural.

Pentingnya kemampuan pemecahan masalah tidak bisa diperdebatkan lagi. Banyak studi dengan menggunakan model yang berbeda telah dilakukan untuk meningkatkan pencapaian hasil belajar kemampuan pemecahan masalah. Pembelajaran berbasis masalah (PBL) merupakan salah satu model pembelajaran yang cocok untuk diaplikasi dalam upaya meningkatkan hasil belajar kemampuan pemecahan masalah siswa.

Ada beberapa teori yang menjadi landasan pembelajaran berbasis masalah. Salah satu di anataranya yaitu teori belajar penemuan (discovery learning). Teori belajar penemuan dikembangkan oleh Jerome Bruner pada tahun 1966. Menurut (Bruner, 1966) belajar penemuan sesuai dengan pencarian pengetahuan secara aktif oleh manusia, dan dengan sendirinya memberikan hasil yang paling baik. Disamping itu, proses belajar ditandai dengan adanya usaha sendiri untuk mencari pemecahan masalah serta pengetahuan yang menyertainya, menghasilkan pengetahuan yang benar-benar bermakna. Belajar melalui penemuan menekankan pentingnya membantu siswa memahami struktur atau ide kunci dari suatu disiplin ilmu, perlunya siswa aktif terlibat dalam pembelajaran, dan suatu keyakinan bahwa pembelajaran yang sebenarnya terjadi melalui penemuan pribadi. Tujuan pendidikan tidak hanya meningkatkan banyaknya pengetahuan siswa tetapi juga menciptakan kemungkinan-kemungkinan untuk penemuan siswa (Arends, 2007)

Pembelajaran berbasis masalah juga berkaitan dengan konsep lain dari Bruner yaitu scaffolding yang memiliki konsep bahwa ketika seseorang yang lebih banyak pengetahuannya diharapkan dapat membantu seseorang yang lebih sedikit pengetahuannya untuk menuntaskan suatu masalah.

Landasan PBL yang lainnya adalah paradigma pembelajaran konstruktivisme. Konstruktivisme merupakan paradigma pembelajaran yang menekankan bahwa pengetahuan adalah merupakan sebuah hasil konstruksi atau bentukan si belajar itu sendiri. Von Glaserfeld menegaskan bahwa pengetahuan bukanlah suatu tiruan dari kenyataan (realitas). Pengetahuan selalu merupakan akibat dari suatu konstruksi kognitif kenyataan melalui kegiatan seseorang.

Pandangan konstruktivis-kognitif yang melandasi perkembangan pembelajaran berbasis masalah banyak didasarkan pada teori Piaget. Pandangan ini mengemukakan bahwa siswa dalam segala usia secara aktif terlibat dalam proses perolehan informasi dan membangun pengetahuan mereka sendiri. Pengetahuan tidak statis tetapi secara terus-menerus tumbuh dan berubah pada saat siswa menghadapi pengalaman baru yang memaksa mereka memodifikasi pengetahuan mereka. Menurut Piaget, pedagogi yang baik harus melibatkan siswa dengan situasi-situasi yang memberikan pengalaman bagi siswa untuk secara mandiri melakukan eksperimen dalam arti yang paling luas, mencoba segala sesuatu untuk melihat apa yang terjadi.

Selain Piaget, ide-ide Vygotsky juga mempengaruhi perkembangan pembelajaran berbasis masalah. Menurut (Vygotsky, 1980) pembelajaran terjadi melalui interaksi sosial dengan guru dan teman sejawat. Melalui tantangan dan bantuan dari guru atau teman sejawat yang lebih mampu, siswa bergerak ke zona perkembangan terdekat mereka dengan begitu pembelajaran baru terjadi (Arends, 2007)

Tujuan dari pembelajaran berdasarkan masalah ada tiga, yaitu membantu siswa mengembangkan keterampilanketerampilan penyelidikan dan pemecahan masalah, memberi kesempatan kepada siswa mempelajari pengalaman-pengalaman dan peran-peran orang dewasa, dan memungkinkan siswa meningkatkan sendiri kemampuan berpikir mereka dan menjadi siswa mandiri. Menurut (Rusman, 2010) yaitu penguasaan isi belajar dari disiplin heuristik dan pengembangan keterampilan pemecahan masalah. PBL juga berhubungan dengan belajar tentang kehidupan yang lebih luas (lifewide learning), keterampilan memaknai informasi, kolaborasi dan belajar tim, dan keterampilan berpikir reflektif dan evaluatif.

(Trianto, 2010) menyatakan bahwa tujuan PBL yaitu membantu siswa mengembangkan keterampilan berpikir dan keterampilan mengatasi masalah, belajar peranan 
orang dewasa yang autentik dan menjadi pembelajar yang mandiri. Sejalan dengan pendapat tersebut, pemecahan masalah merupakan salah satu strategi pengajaran berbasis masalah dimana guru membantu siswa untuk belajar memecahkan melalui pengalaman-pengalaman pembelajaran hands-on, sehingga pernyataan tersebut sesuai dengan tujuan dari penelitian ini yaitu untuk mengetahui pengaruh PBL terhadap kemampuan pemecahan masalah yang diukur dari beberapa kemampuan kognitif yaitu (1) C3 (mengaplikasikan), (2) C4 (menganalisis), (3) C5 (mengevaluasi), dan (4) C6 (mencipta).

\section{METODE}

Jenis penelitian adalah penelitian tindakan kelas yang dilakukan secara kolaboratif. Dalam penelitian kolaboratif pihak yang melakukan tindakan adalah pembelajar sedangkan yang diminta melakukan pengamatan terhadap berlangsungnya proses tindakan adalah peneliti (Arikunto, 2009)

Model penelitian tindakan kelas yang digunakan adalah model yang dibuat oleh Kemmis dan Taggart yang merupakan pengembangan dari model Kurt Lewin. Model ini dapat mencakup beberapa siklus dan pada masing-masing siklus meliputi tahapan yaitu: (1) Planning atau perencanaan, (2) Acting and observing atau pelaksanaan dan observasi, (3) Reflecting atau refleksi, dan (4) Revise plan atau revisi perencanaan. Tahapan-tahapan tersebut berlangsung secara berulangulang sampai tujuan penelitian tercapai.

Penelitian dilakukan dalam dua siklus. Siklus dihentikan apabila kondisi kelas sudah stabil dalam hal ini dosen sudah mampu menguasai keterampilan belajar yang baru dan mahasiswa terbiasa dengan model pembelajaran Problem Based Learning serta data yang ditampilkan di kelas sudah jenuh dalam arti sudah ada peningkatan keaktifan dan prestasi belajar mahasiswa (Wriatmadja, 2006)

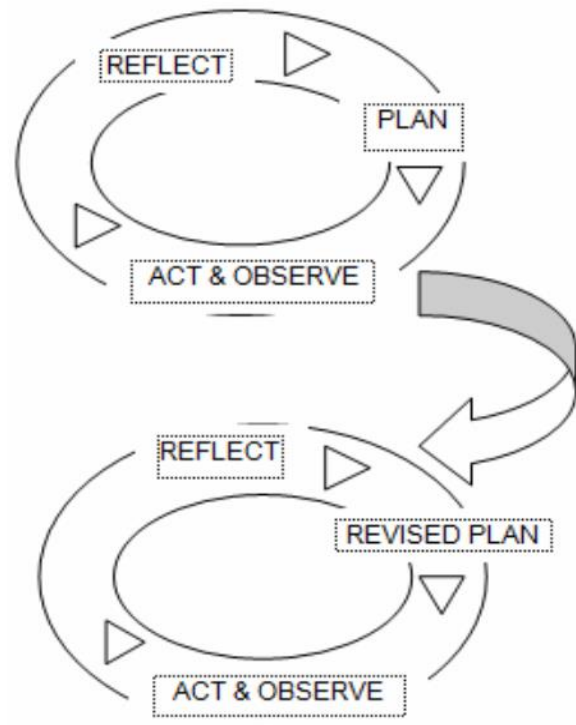

Gambar 1. Alur penelitian menurut model Spiral dari Kemmis dan Taggart
Subyek penelitian adalah mahasiswa S1 Pendidikan Tata Busana Angkatan 2013 Kelas B Universitas Negeri Surabaya sejumlah 30 mahasiswa. Sedangkan obyek penelitian adalah kompetensi membuat pola kemeja pria. Instrumen penelitian yang digunakan terdiri dari dua jenis instrumen. Instrumen pertama yaitu instrumen untuk pembelajaran yaitu: (1) silabus, (2) satuan acara perkuliahan (SAP), (3) hand out, (4) lembar kerja mahasiswa. Sedangkan instrumen kedua adalah instrumen yang digunakan untuk mengumpulkan data yaitu (1) tabel spesifikasi lembar penilaian, dan (2) lembar penilaian (LP).

Pada penelitian tindakan kelas ini, kelompok skor ditentukan menjadi 4 kategori (4 kelompok skor). Untuk itu diperlukan jumlah butir valid, skala nilai dari 1 sampai 4 (skala likert 4) dimana 4 merupakan nilai tertinggi (nilai maksimum) dan 1 merupakan nilai terendah (nilai minimum). Dari perkalian jumlah butir valid dengan nilai terendah (minimum) akan diperoleh skor terendah (skor minimum). Dan dari perkalian jumlah butir valid dengan nilai tertinggi (nilai maksimum) kita peroleh skor tertinggi (skor maksimum).

Selanjutnya dari skor maksimum sampai skor minimum tersebut kemudian dibagi menjadi 4 kelompok skor (interval nilai), yaitu sangat baik, baik, kurang, dan sangat kurang. Kriteria penilaian pembelajaran pembuatan pola kemeja pria dengan menggunakan model pembelajaran berdasar masalah (problem based learning) secara umum dapat dilihat pada Tabel 1.

Tabel 1. Kriteria Penilaian Kompetensi Membuat Pola Kemeja Pria dengan Menggunakan Model Pembelajaran Berdasar Masalah

\begin{tabular}{|c|c|c|}
\hline Klas & Interval Nilai & Interprestasi \\
\hline 1 & $S_{\min } \leq S \leq\left(S_{\min }+p-1\right)$ & Sangat Kurrang \\
\hline 2 & $\left(S_{\min }+p\right) \leq S \leq\left(S_{\min }+2 p-1\right)$ & Kurang \\
\hline 3 & $\left(S_{\min }+2 p\right) \leq S \leq\left(S_{\min }+3 p-1\right)$ & Baik \\
\hline 4 & $\left(S_{\min }+3 p\right) \leq S \leq S_{\max }$ & Sangat Baik \\
\hline
\end{tabular}

\section{HASIL DAN PEMBAHASAN}

\section{Hasil penelitian}

Tabel 2. Hasil Belajar Mahasiswa LP 1 Pengetahuan

\begin{tabular}{ccccc}
\hline Siklus & \multicolumn{2}{c}{ Lulus } & \multicolumn{2}{c}{ Tidak Lulus } \\
\cline { 2 - 5 } & Jmh Siswa & $\%$ & Jmh Siswa & $\%$ \\
\hline I & 16 & 53,33 & 14 & 46,67 \\
II & 30 & 100 & 0 & 0 \\
\hline
\end{tabular}




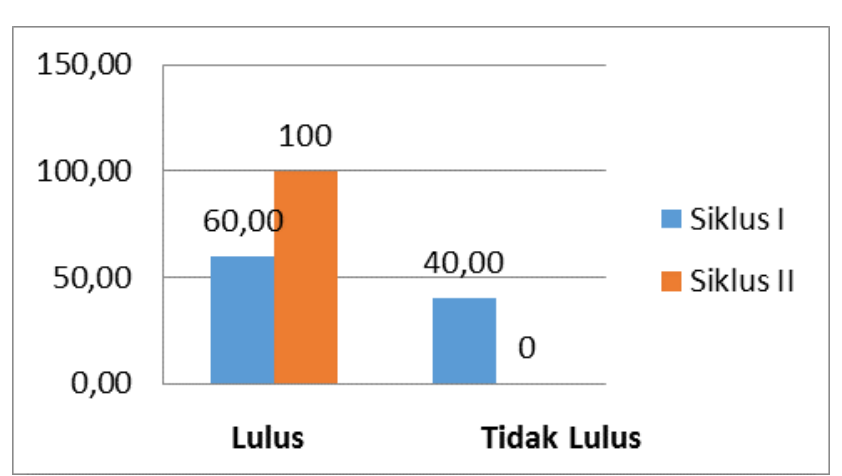

Gambar 2. Diagram Hasil Belajar Mahasiswa LP 1 Pengetahuan

Tabel 3. Hasil Belajar Mahasiswa LP 2: Membuat Pola Kemeja

\begin{tabular}{ccccc}
\hline Siklus & \multicolumn{2}{c}{ Lulus } & \multicolumn{2}{c}{ Tidak Lulus } \\
\cline { 2 - 5 } & $\begin{array}{c}\text { Jmh } \\
\text { Siswa }\end{array}$ & $\%$ & $\begin{array}{c}\text { Jmh } \\
\text { Siswa }\end{array}$ & $\%$ \\
\hline I & 23 & 76,67 & 7 & 23,33 \\
II & 30 & 100 & 0 & 0 \\
\hline
\end{tabular}

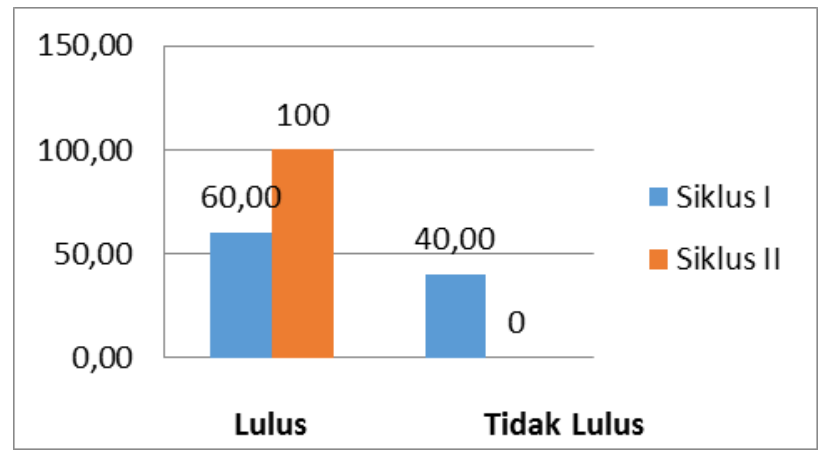

Gambar 3. Diagram Hasil Belajar Mahasiswa LP 2 Membuat Pola Kemeja Pria

Tabel 4 Hasil Belajar Mahasiswa LP 3: Ujicoba Pola Kemeja

\begin{tabular}{ccccc}
\hline \multirow{2}{*}{ Siklus } & \multicolumn{2}{c}{ Lulus } & \multicolumn{2}{c}{ Tidak Lulus } \\
\cline { 2 - 5 } & Jmh Siswa & $\%$ & Jmh Siswa & $\%$ \\
\hline I & 15 & 50 & 15 & 50 \\
II & 30 & 100 & 0 & 0 \\
\hline
\end{tabular}

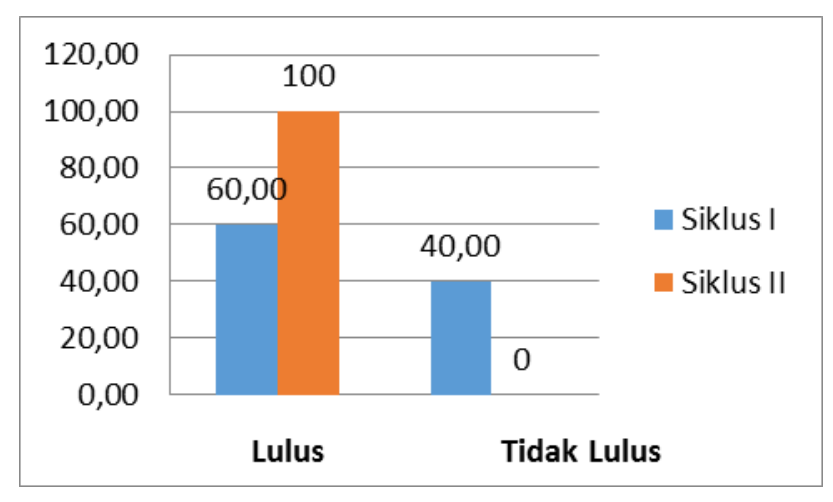

Gambar 4 Diagram Hasil Belajar Mahasiswa LP 3: Ujicoba Pola

Tabel 5. Hasil Belajar Mahasiswa LP 4: Produk

\begin{tabular}{ccccc}
\hline \multirow{2}{*}{ Siklus } & \multicolumn{2}{c}{ Lulus } & \multicolumn{2}{c}{ Tidak Lulus } \\
\cline { 2 - 5 } & Jmh Siswa & $\%$ & Jmh Siswa & $\%$ \\
\hline I & 18 & 60 & 12 & 40 \\
II & 30 & 100 & 0 & 0 \\
\hline
\end{tabular}

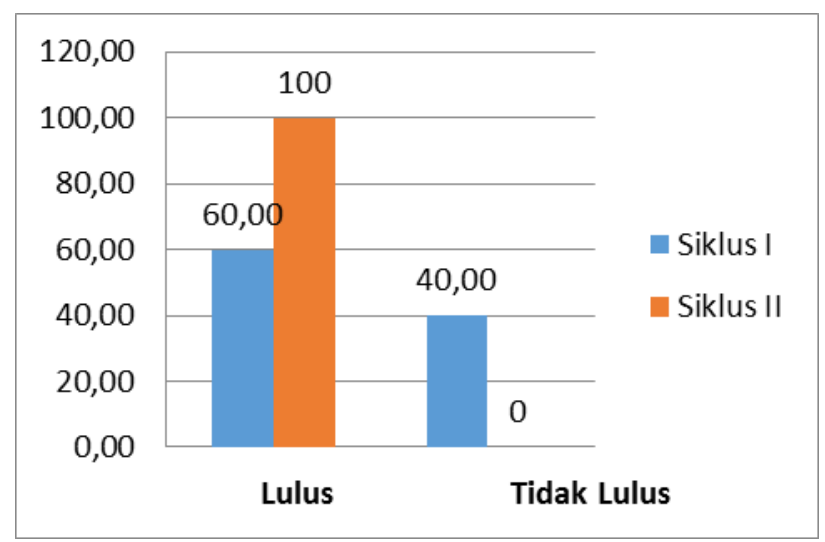

Gambar 5. Diagram Hasil Belajar Mahasiswa LP 4: Produk

Hasil belajar diukur dengan menggunakan lembar penilaian yang tercantum pada perangkat pembelajaran membuat pola kemeja pria, yang terdiri atas: LP 1: Pengetahuan, LP 2: Membuat Pola Kemeja Pria, LP 3: Ujicoba Pola Kemeja, LP 4: Produk, LP 5: IPTEK, dan LP 6: Sikap. Ketuntasan belajar mahasiswa didasarkan pada kriteria ketuntasan minimal yang diterapkan Djemari yaitu sebesar $\geq 75$ untuk ketuntasan individu dan $\geq 75 \%$ untuk ketuntasan klasikal. Hasil analisis ketuntasan belajar mahasiswa dapat dilihat pada Tabel 2.

Berdasarkan pada Tabel 2, nilai LP 1: Pengetahuan pada siklus 1 terdapat 14 mahasiswa yang dinyatakan tidak tuntas dikarenakan nilai yang didapat $\leq 75$, dan 26 mahasiswa telah dinyatakan tuntas dikarenakan nilai yang diperoleh $\geq 75$. Namun pada rata-rata nilai kelas sebesar 73,17 dinyatakan belum tuntas. Pada siklus II untuk nilai LP 1: Pengetahuan, semua mahasiswa dinyatakan tuntas dengan nilai rata-rata kelas sebesar 
80.17. Hal ini menunjukkan bahwa hasil belajar secara klasikal dinyatakan tuntas.

Data pada Tabel 3 untuk nilai LP 2: Membuat pola kemeja pria pada siklus 1 terdapat 7 mahasiswa yang dinyatakan tidak tuntas dikarenakan nilai yang didapat $\leq$ 75, dan 23 mahasiswa telah dinyatakan tuntas dikarenakan nilai yang diperoleh $\geq 75$. Namun pada ratarata nilai kelas sebesar 71,67 dinyatakan belum tuntas. Sedangkan pada pada siklus II untuk nilai LP 2: membuat pola kemeja pria, semua mahasiswa dinyatakan tuntas dengan nilai rata-rata kelas sebesar 76,50. Hal ini menunjukkan bahwa hasil belajar secara klasikal dinyatakan tuntas.

Selanjutnya pada Tabel 4 untuk nilai LP 3: Uji coba pola kemeja pria pada siklus 1 terdapat 15 mahasiswa yang dinyatakan tidak tuntas dikarenakan nilai yang didapat $\leq$ 75, dan 15 mahasiswa telah dinyatakan tuntas dikarenakan nilai yang diperoleh $\geq 75$. Namun pada ratarata nilai kelas sebesar 71,17 dinyatakan belum tuntas. Sedangkan pada siklus II untuk nilai LP 3: ujicoba pola kemeja pria, semua mahasiswa dinyatakan tuntas dengan nilai rata-rata kelas sebesar 75,83. Hal ini menunjukkan bahwa hasil belajar secara klasikal dinyatakan tuntas.

Sedangkan pada Tabel 5 untuk nilai LP 4: Produk, berupa pola kemeja pria pada siklus 1 terdapat 18 mahasiswa yang dinyatakan tidak tuntas dikarenakan nilai yang didapat $\leq 75$, dan 12 mahasiswa telah dinyatakan tuntas dikarenakan nilai yang diperoleh $\geq 75$. Namun pada rata-rata nilai kelas sebesar 71, 83 dinyatakan belum tuntas. Sedangkan pada pada siklus II untuk nilai LP 4: produk pola kemeja pria, semua mahasiswa dinyatakan tuntas dengan nilai rata-rata kelas sebesar 80.50. Hal ini menunjukkan bahwa hasil belajar secara klasikal dinyatakan tuntas.

\section{Pembahasan}

Berdasarkan hasil analisis dari siklus satu sampai kedua ternyata terdapat peningkatan kemampuan mahasiswa dalam membuat pola kemeja pria. Keterlaksanaan pembelajaran berbasis masalah untuk meningkatkan kemampuan mahasiswa juga mengalami peningkatan. Dari beberapa observasi keterlaksanaan pada tahap orientasi masalah, kegiatan pembelajar dalam memotivasi si belajar untuk terlibat aktif dalam pembelajaran belum terlaksana secara optimal. Kemudian pada tahap pengorganisasian, pengaturan penggunaan waktu belum optimal, sehingga tampak pada siklus I, waktu untuk pembelajar dalam memberikan konfirmasi hasil presentasi kurang lama. Selanjutnya pada tahap pebimbingan investigasi, kegiatan mengusahakan mahasiswa untuk terlibat aktif dan saling berinteraksi belum optimal dilakukan. Hal ini dikarenakan model PBL merupakan model pembelajaran yang baru sehingga butuh penyesuaian kondisi kelas.
Memasuki siklus II terdapat perbaikan dari pelaksanaan siklus I, tampak hasil yang dicapai si belajar juga meningkat dari setiap aspek belajar. Pada pelaksanaan pembelajaran siklus II, tahap pembelajaran model PBL telah terlaksana semuanya. Tahap orientasi masalah pada kegiatan memotivasi si belajar untuk terlibat aktif telah dilakukan. Pengaturan penggunaan waktu juga telah dilakukan, dalam hal ini Pembelajar memberi waktu diskusi selama 30 menit, lebih singkat dibanding siklus I. Hal ini dilakukan supaya waktu untuk presentasi lebih awal dan waktu untuk pembelajar dalam klarifikasi hasil presentasi juga lebih lama. Tahap selanjutnya adalah membimbing penyelidikan si belajar, kegiatan pembelajar dalam mengusahakan si belajar untuk terlibat aktif dan saling berinteraksi telah dilakukan. Indikasi keaktifan dan interaksi si belajar tampak pada saat pembelajar menanyakan kembali permasalahan yang terdapat dalam LKM serta memberikan pertanyaan secara klasikal. Pertanyaan yang diberikan dimaksudkan untuk merangsang sejauh mana pengetahuan si belajar dalam mengenali permasalahan yang diberikan. Si belajar yang tahu, segera mengangkat tangan dan mengemukakan pendapat. Dalam hal ini pembelajar tidak segera membenarkan jawaban si belajar, namun memberi kesempatan yang lain untuk menyempurnakan jawaban. Dari kegiatan ini, pembelajar beserta si belajar aktif dalam proses pembelajaran, dimulai dari memikirkan permasalahan, mengidentifikasi penyebab permasalahan, merancang solusi sampai dengan membuat kesimpulan akhir.

\section{SIMPULAN DAN SARAN}

\section{Simpulan}

Berdasarkan hasil penelitian dan pembahasan, model pembelajaran berbasis masalah mampu menghasilkan peningkatan kemampuan pemecahan masalah pada kompetensi membuat pola kemeja pria. Selain itu, ditemukan pula efek lanjutan dari penerapan model pembelajaran berbasis masalah ini yaitu adanya keaktifan dan sikap sosial yang relevan dengan pembelajaran.

\section{Saran}

Berdasarkan kesimpulan maka beberapa saran yang diusulkan sebagai upaya perbaikan adalah sebagai berikut:

1. Model Problem Based Learning dapat digunakan dan dikembangkan sebagai upaya meningkatkan kualitas pembelajaran, karena berdasarkan penelitian mahasiswa dapat meningkatkan kemampuan berpikir, mengemukakan pendapat, aktif mengajukan pertanyaan, bekerja sama, dan mandiri dalam belajar.

2. Bagi mahasiswa, Dosen, dan semua pihak agar terus berusaha mengembangkan dan mencari inovasi kreatifitas pembelajaran tata busana terutama yang berkaitan dengan penerapan model Problem Based Learning.

3. Bagi peneliti lain yang berkeinginan untuk mengadakan penelitian sejenis sebaiknya tidak hanya membatasi tentang upaya peningkatan kemampuan 
mahasiswa dalam menyelesaikan permasalahan, tetapi juga variabel lain yang ditingkatkan dan bidang lain.

\section{DAFTAR PUSTAKA}

Adistana, G. A. Y. P. (2016). Pengaruh Blended Learning Station-Rotation (Kooperatif Vs Kompetitif) Dan Gaya Kognitif, Terhadap Keterampilan Intelektual Manajemen Konstruksi. DISERTASI Dan TESIS Program Pascasarjana UM.

Arends, R. I. (2007). Learning to Teach Belajar untuk Mengajar. yogyakarta: Pustaka Belajar.

Arikunto, S. S. dan S. (2009). Penelitian Tindakan Kelas. Jakarta: Bumi Aksara.

Bruner, J. S. (1966). Toward a theory of instruction (Vol. 59). Harvard University Press.

Chaudhry, N., \& Rasool, G. (2012). A case study on improving problem solving skills of undergraduate computer science students. World Applied Sciences Journal, 20(1), 34-39.

Rusman. (2010). Model-model Pembelajaran. Jakarta: Raja Grafindo Persada.

Trianto. (2010). Mendesain Model Pembelajaran Inovatif Progresif. Jakarta: Kencana Predana Media Group.

Vygotsky, L. S. (1980). Mind in society: The development of higher psychological processes. Harvard university press.

Wriatmadja, R. (2006). Metode Penelitian Tindakan Kelas Untuk Meningkatkan Kinerja Guru dan Dosen. Bandung: Rosda. 